\title{
New Service Delivery Alternatives from the Automation of Knowledge with Virtual Assistants
}

\author{
Francisco Gonzalez Bree
}

Deusto Business School, University of Deusto, Spain

Copyright $(\mathcal{C} 2015$ by authors, all rights reserved. Authors agree that this article remains permanently open access under the terms of the Creative Commons Attribution License 4.0 International License

Abstract Companies have been deploying for the last 45 years Technology Based Self-Service systems (TBSS) such as ATMs as a means of replacing human centered interaction with technology in the process of service creation with their customers. Since the year 2010 companies have begun introducing more sophisticated information and communication technologies like Virtual Assistants (VAs) that allow people to interact verbally with cars, navigation devices, smart phones, PCs, tablets etc. (e.g. SIRI, Sher.pa). The companies working in the VA industry are starting to develop these systems for the wearable devices industry. Soon we will be able to interact with a VA in the form of Google Glass or Apple iWatches. Furthermore these companies are starting to test new service delivery alternatives. TBSS research is not able to keep pace with technological developments, therefore the generalisability of extant knowledge to these new technologies remains un-answered. Responding to the above observations, the aim of this study is explorative as it seeks to formulate problems, clarify concepts in order to create hypotheses and a conceptual model in a forthcoming paper. This study involved a thorough review of extant literature, exploratory face-to-face and telephone interviews with experts from different disciplines. Insights obtained from the study suggest the following points: (1) in the future there will be space in the marketplace for the three types of service deliveries identified in the literature: (a) humans, (b) TBSS and (c) intelligent machines such as VAs. (2) Despite the introduction of these new intelligent systems, customers will continue performing the service or parts of the service by themselves with the use of TBSS systems. (3) Users will not be able to absorb all the technological developments at the same speed as the innovations are coming out into the marketplace. (4) Finally intelligent machines such as VAs will foster new innovative service delivery alternatives in which the firm will act together with external parties through informal arrangements or formal alliances with a collaborative mindset. These insights make the following important contributions to the subject matter.

Keywords Disruptive Technologies, Automation of Knowledge Work, Internet of Things, Virtual Assistants, Technology Based Self-service, Customer Service

\section{The Evolution of Definitions of Services}

Lovelock and Wright [1] provided a general definition of services stating that "a service is an act or performance offered by one party to another". The process might be tied to a physical product (i.e. an ATM) but the performance and the outcomes are essentially intangible. Therefore services can be considered as economically valuable and beneficial activities for customers at specific times. Zeithhaml and Bitner [2] stated that services can be classified in "deeds, processes and performances". Following this definition, Vargo and Lusch [3] stated that services can be defined as "the application of specialized competences (knowledge and skills) through deeds, processes and performances for the benefit of another entity or the entity itself".

In general services are more difficult for customers to evaluate than goods due to the preponderance of experience and credence attributes in most services, as opposed to the dominance of search attributes in most goods (Lovelock and Wright [1]). Given their inherent characteristics services are also much more prone to be delivered via electronic channels, while with products at one point or another it will be necessary to use physical distribution channels from producer to end consumer (Lovelock and Wright [1]). As a result of the above characteristics it can be argued that customers do not obtain ownership of a service (Lovelock and Wright [1]) while they are usually involved in the service production process (Kelly et al. [4]). Since customers actively participate in the production of a service they request, they are also intrinsically linked to the outcome of the service process (Gummesson [5]). As a consequence of their participation in the act of service creation, consumers feel more responsible for the level of satisfaction or dissatisfaction they attain, compared with the consumption of physical goods (Meuter et al. [6]).

\section{Services and Technology}

The confluence of various marketing research fields such 
as services marketing, relationship marketing and services has led to the service-centered view developing as the new dominant logic for the discipline (Vargo and Lusch [3]). In this logic, services are viewed as the dominant part of the value creation process (Gummesson [5]) and the customer plays an important active role in such process (Czepiel [7], Lovelock and Wright [1], Zeithaml and Bitner [2]).

The service-centered view of marketing is customer-centric (Sheth et al. [8]) and market driven (Day [9]). This view implies collaborating with and learning from customers and being adaptive to their individual and dynamic needs. The service-centered view implies that value is defined by and co-created with the consumer rather than embedded in output (Vargo and Lusch [3]). Regarding this shifting to co-production activities, firms are also recognizing that, particularly in service contexts, customers are actually co-creators of the service and that the value derived from the service comes through usage and co-creation rather than exclusively through service provision or delivery in the traditional sense (Vargo and Lusch [3]), Michel et al. [10]).

Developments in technology such as the Internet are supporting the ways in which companies interact with their customers in this new service-centered view (Bitner et al. [11]). As a consequence, companies are able to improve communication and speed up their processes (Froehle [12]). Technology is improving the ways in which impersonal services can complement or replace the human element in the process of service creation (Bitner et al. [11). For example there are now sophisticated information and communication technologies like VAs that allow people to interact verbally with their cars, navigation devices, smart phones, PCs, tablets etc. (e.g. SIRI, Sher.pa). The companies working in the VA industry are starting to develop these systems for the wearable devices industry. Soon we will be able to interact with a VA in a Google Glass or an Apple iWatch. But the possibilities for VAs go further than this. The latest digital technologies are starting to be integrated in previously non-digital products and services such as cars, fridges, thermostats etc. This phenomenon has been coined by the Auto-ID as the Internet of Things (IoT). Another related phenomenon is the Smart City which combines aspects of Internet of Things applied to the management of cities. IBM defined a Smart City as a city that can make its system instrumented, interconnected and intelligent with sensors scattered around the city. Review of the literature revealed that there are very few studies investigating this constant evolution of technologies and business models that are now blurring the line between industries.

\section{Technology Based Self-Service (TBSS)}

One services and technology field that has received attention by academics and practitioners and from which we can draw some insights is the area of Technology Based Self-Service systems. In the 1960s the potential of TBSS to complement or to replace personal services performed by human service employees was starting to be explored at a time when services were considered less important in economic value creation than commodities (Regan [13]). Since then TBSS has increased its role due to advances in technology growth and the consumer acceptance of these technological interfaces (Bitner et al. [11]).

Anselmsson [14]) explained TBSS as "any activity or benefit based on hard technologies that service providers offer so that customers can perform the service, or parts of the service, by themselves" (Dabholkar [15], [16]). The difference with traditional service is the aspect of who performs the service, the employee or the customer (Anselmsson [14]). In the case of TBSS systems the service provider is a machine used by the customer in order to perform the service by him or herself making it possible to replace the human service employees who were necessary in traditional service delivery (Bitner et al. [11]).

Research has recognized the benefits of TBSS for customers including savings in time and cost, greater control over the service delivery, reducing waiting time, a higher perceived level of customization (Meuter and Bitner [17]), enjoyment from using the technology (Dabholkar [15], [16], [18]) efficiency, flexibility, spontaneous delight (Bitner et al. [11]) and ultimately greater satisfaction (Meuter et al. [6]). Research has also found that TBSS reduces costs and provides opportunities to increase the speed of delivery, precision, customization, productivity, market share, customer satisfaction and customer loyalty and differentiates by way of technological reputation (Meuter and Bitner [17]).

Other authors view TBSS as detrimental to the quality of service and assistance provided to consumers (Newholm et al. [19]). Therefore, an efficient application of TBSS can provide a company with the opportunity to build, maintain and enhance the relationship with its customers. For this purpose it is important that the company understands which types of services can be migrated to TBSS and which customers will accept such change in using the technology.

\section{Types of Services}

There are several classification schemes for TBSS that have a focus on how the service is delivered. Dabholkar [15], [16] distinguished between person-to-person and person-to-technology service encounters. Anselmsson [14] proposed four situations, direct contact at service site, direct contact at customer's site, indirect contact at service site and indirect contact at customer's site. Dabholkar and Bagozzi [21] focused on on-site options and off-site options. Schultze [22] developed a categorization based on personal and impersonal services. Sousa and Voss [23] introduced a classification based on physical and virtual services. 
Froehle [12] proposed face-to-face and face-to-screen service situations. More recently Cunningham et al. [24] offered several service categories based on two dimensions customized-standardized and separable-inseparable.

Alba et al. [20] argued that although the purpose of TBSS is comprehensively, the form of the interface it is subject to constant technological evolution. This author argues that this point is relevant to the current study because not only the interfaces but also the purposes are now blurring the line between the different categories (i.e. VAs can be used for customer service, transactions and self-help in Wearable Devices or objects from the Internet of Things).

The latest technologies such as VAs (5th generation) incorporate natural-language processing (NLP), semantic technologies, dialogue control, domain knowledge and visual appearance. As a consequence these more sophisticated VAs can understand concepts, can act based on multiple questions in one sentence, support proactive sales and marketing efforts, include analytics and feedback management. These systems are able to understand and more important deliver services to the customer without the customer co-producing parts of the service as in the TBSS logic. Consequently, this example illustrates that there has been a rapid change and evolution of TBSS to intelligent services making it necessary to review current categorizations.

\section{The Business Model and Value Proposition of Each Type of Service Delivery}

One important aspect of this study is related to the business model and value proposition of the types of service delivery options. Therefore this author is including a brief description of both concepts. Osterwalder and Pigneur [25] proposed a business model as a visual conceptual tool that can help understand how a firm does business. Within the business model, the value proposition is considered the core element and it has been defined as an overall view of a firm's bundle of products and services that together represent value for specific customer segments.

The business model can be used for different activities of the firm such as analysis, comparison, assessment, management, communication, and innovation. Business models visualize the way the firm defines its competitive strategy through the design of the product or service it offers to its market, It looks to the revenue streams and costs, how it differentiates itself from other firms by the value proposition, and how the firm integrates its own value chain to those of other firms in a value network (Rasmussen [26]). Business models have received important attention in literature and business and it is increasingly suggested that business model innovation increases business performance (Chesbrough [27], Zott et al. [28]). The literature offers different views on the business model: Margretta's [29], Zott and Amit [30] and Beattie and Smith [31] describe business models as a holistic description on 'how a firm does business'. Teece [32] proposed that a business model articulates how the company will convert resources and capabilities into economic value. In this study business models were used as a complementary view on the current situation and possible evolution of services delivered by humans, TBSS and Intelligent services. The focus was placed on the value proposition, customer segment and revenue stream parts of the business model by Osterwalder and Pigneur [25].

\section{Data and Research Methodology}

The goal of this inductive study is explorative as it seeks to formulate problems, clarify concepts and create hypotheses. This study involved a thorough review of extant literature and research and exploratory face-to-face and telephone interviews with experts from different disciplines and fields. The decision to seek information from experts is in line with Dalebout and Wierenga's [33] assertions on the importance of soliciting expert opinions and perceptions about complex business and management phenomena. Using experts during the exploratory phase is recognised by scholars as a valid way of obtaining consensus and developing a holistic appreciation of the relevant issues (Winkler [34]). In line with Kent [35] discussion with experts:

- Increased this author's familiarity with the topic under investigation.

- Diagnosis, analysis and evaluation of the nature of potential research problems.

- Establishment of the priorities and objectives of a research investigation to decide which particular issues merited further investigation.

- Information related to practical problems involved with the research, such as issues of data collection and sampling.

- Ideas, insights and suggestions for hypotheses that could be tested.

Interviews were held with experts from:

- $\quad$ TBSS Industry - Head Marketing LatAm and Spain at WIncor Nixdorf.

- VAs Industry - Founder and CEO of Anboto and Sherpa.

- Psychology - Business partner and Advisor of several IT firms.

- Digital Business Model \& Marketing - VP, Partner and CEO of several Digital Marketing Firms such as Blackout.

- Social Business \& Social Collaboration Consultant of Social Business Solutions for Social Collaboration at IBM.

During the explorative interviews, the experts were asked their opinions on five open questions:

(1) What is your view about services provided by human employees? 
(2) What is your view about services provided by TBSS systems?

(3) What is your view about services provided by intelligent systems such as VAs?

(4) Do you think there will be a migration from one type of service delivery to another (I.e. In the future people will prefer to be served by intelligent systems rather than doing the service by themselves with TBSS systems).

(5) What business models fit better for each of the above type of service delivery methods?

Although these questions guided the interviews, the sessions were open to allow the expert informants to make other comments they might believe that could be interesting for the study.

\section{Research Findings}

The experts believed that nowadays and in the future from a user point of view there will be room for the three types of service deliveries, (services delivered by humans, Technology Based Self-service systems and services delivered by intelligent systems like VAs) (see table 1). The experts considered that although some migration might occur between types of services, still the three types will offer value for certain customer segments. Experts are not sure that people will be able to absorb the accelerating evolution of technological advances at the same time as innovations are reaching the marketplace. Finally experts believe that in the case of services delivered by intelligent machines, there will be opportunities to develop new business models.

\section{Discussions and Conclusions}

The discussions of this study are presented next and the conclusions and suggestions for further research are offered at the end of the section.

Services delivered by humans: The experts believed that in the future there will be room for this type of services particularly if the service is complex, there are problems or there is a need for negotiation. This author argues that these views are aligned with literature on services. Some people have a preference to be served by a human rather than by a machine, this variable is known as Need for Interaction (Dabholkar and Bagozzi [21], Curran and Meuter [36] and it has been defined as the importance of giving human interaction to the customer in the service encounter (Dabholkar [18]) This can be particularly important in cases of complex services, problems with services or high level or luxury services (E.g. Massages at a 5 star hotel or employees working at a jewellery shop). One comment made by the experts was related to services prone to some negotiating where the customer would rather negotiate with a human than a machine. As one expert pointed out 'I don't see myself negotiating with a robot and trying to convince the robot about something it has not been programmed for".

Table 1. Summary of the view of experts about the potential mix of type of services

\begin{tabular}{|c|c|c|}
\hline Type of service & $\begin{array}{l}\text { Description of the reasons that support the } \\
\text { need for a specific type of service }\end{array}$ & $\begin{array}{l}\text { Description of the business model and value proposition that support a } \\
\text { specific type of service }\end{array}$ \\
\hline $\begin{array}{l}\text { Services delivered by } \\
\text { humans (E.g. bank } \\
\text { employee at a } \\
\text { branch) }\end{array}$ & $\begin{array}{l}\text { This type of service delivery will be useful } \\
\text { in cases when the customer prefers to be } \\
\text { attended by a human and/or the service is } \\
\text { complex or there are problems with the } \\
\text { service. The reason is that humans can } \\
\text { explain the problem to the customer in a } \\
\text { human way, they can reassure the } \\
\text { customer, and they can be empathic }\end{array}$ & $\begin{array}{l}\text { The value proposition for the company using human employees for some } \\
\text { service deliveries is built around increasing customer satisfaction, } \\
\text { customer loyalty and company reputation. The value proposition for the } \\
\text { final user is built around resolving complex needs or problems with } \\
\text { employees that are experts in their disciplines or fields of service and/or are } \\
\text { excellent at customer service practices delivering memorable experiences }\end{array}$ \\
\hline $\begin{array}{c}\text { Technology Based } \\
\text { Self-service systems } \\
\text { (E.g. ATM) }\end{array}$ & $\begin{array}{l}\text { This type of service delivery will be useful } \\
\text { in cases when the service is predictable, } \\
\text { repetitive, simple and the customer sees } \\
\text { value in taking control and doing the } \\
\text { service by him or herself }\end{array}$ & $\begin{array}{l}\text { The value proposition for the company acquiring the TBSS system is built } \\
\text { around increasing productivity and reducing costs. With TBSS systems the } \\
\text { company could migrate the human employees to do more valuable and } \\
\text { complex tasks. The value proposition for the final user is built around } \\
\text { reducing waiting time, convenience, flexibility and greater control }\end{array}$ \\
\hline $\begin{array}{l}\text { Services delivered by } \\
\text { intelligent machines } \\
\text { (E.g. Virtual } \\
\text { Assistants } 5^{\text {th }} \\
\text { generation) }\end{array}$ & $\begin{array}{l}\text { This type of service delivery will be useful } \\
\text { in cases when the customer prefers to be } \\
\text { attended by an intelligent machine and } \\
\text { there is clear added value for using this } \\
\text { technology }\end{array}$ & $\begin{array}{l}\text { The value proposition for the company acquiring the intelligent machine is } \\
\text { built around productivity, reducing costs and increasing sales (with } \\
\text { techniques such as upselling or cross-selling). The value proposition for } \\
\text { the final user is built around the "high added value". It is like having you } \\
\text { own intelligent servant that can be reactive or proactive, can focus on } \\
\text { specific tasks or it can serve you an array of your needs. Experts argued } \\
\text { that these systems open possibilities for "Triple Helix Business Models" } \\
\text { combining private sector, public sector, educational sector }\end{array}$ \\
\hline
\end{tabular}


The literature suggests several benefits for using personal service situations. Customers can influence the outcome of the service process directly through interaction with the service employee (Svensson [37]). Furthermore, the behaviour of frontline service personnel as well as the interaction between them and the customers are very important for a service company's image (Harris and Ogbonna [38]), particularly in the case of a service failure. As the service is delivered by the company's employee, a failure in the service may be attributed to the employee (Bitner et al. [39]). On the other hand, there are good opportunities for service recovery because the customer and service employee interact directly (Yen et al. [40]). The customer can show his disappointment in real time if the service level performed does not meet his expectations and the service employee has the chance to react accordingly and to correct the situation (Swanson and Kelley [41]). This is very important, since effective service recovery has been found to increase the customer's perceived level of service quality, even compared with situations where no service failures have occurred (Bitner et al. [42]).

Technology Based Self-service systems: The experts believed that in the future there will be room for this type of services particularly if the service is simple and predictable. In fact the experts believe that this type of service will grow in the future because there is clear value for the customer that deploys the system and the user that uses it. The experts commented that one of the key benefits of TBSS for users is that it has made it possible for Low-cost companies to offer cheap prices and their business model is designed around this aspect. As one expert pointed out "Thanks to these self-service technologies people can travel today for very low prices". Therefore the experts believe that the business rationale in this case is so powerful that firms will continue migrating services from human to TBSS systems.

This author argues that these views are aligned with literature on services (see point 3 ). For some people it will be very important that the technology is easy to be use and useful (Dabholkar and Bagozzi [21], Curran and Meuter [36]). Using TBSS includes benefits such as time saving, more control, flexibility etc. Some people have a desire to seek new stimuli and the variable that explains this characteristic is known as Inherent Novelty Seeking (Dabholkar and Bagozzi [21]). In this line, research has found that while some customers find the interaction with service employees enjoyable, other customers consciously try to avoid personal service encounters, as they are not comfortable dealing with service employees (Meuter et al. [6], Dabholkar et al. [43]).

Services delivered by intelligent machines: The experts believed that in the future there will be room for this type of services when there is clear added value for the customer. As one expert working in the VAs sector explained the value proposition to sell VAs is very attractive for the customer. "if you purchase this Virtual Assistant $5^{\text {th }}$ Generation from us it will help you significantly by increasing your sales and reducing your costs". Also for the final users these systems will provide high added value because these intelligent systems can act for you delivering many services in an array of sectors and disciplines: banking, retail, tourism, health, etc. For the final users it is like having a virtual banker, virtual doctor, virtual teacher, virtual steward etc.

One of the problems with these technologies is that there are very few empirical studies that explain the adoption, benefits and weaknesses of these systems. For example Lind and Salomonson [44] investigated in their paper "The Role of Virtual Servants in e-Interaction", the case of the virtual servant - Anna at Ikea. The authors concluded that virtual servants support the potential /particular buyer in navigating on the company's web-site rather than the realization of a purchase. The problem is that the virtual servant Anna at Ikea technology is considered by experts to be quite old already $\left(1^{\text {st }}\right.$ generation $)$ compared to the latest virtual assistants $\left(5^{\text {th }}\right.$ generation). A $1^{\text {st }}$ generation VAs is more a TBSS system than an intelligent system. Another issue that merits attention with these new technologies is related to their business model. In the case of virtual assistants there are several business models being tested nowadays in the market that were explained in this study by the experts:

Business-to-Business: In this logic a private company designs, sells, installs and maintains a VA for another company or organization. An example is the case of Anboto a company that has been selling VAs for banks, retailers, airlines etc. In this case the VA is connected to the customer's database therefore the VA is able to provide services related to the activities of the customer. (E.g. In the case of a retail firm, the virtual assistant can provide information about products, outstanding orders or it can help with the realization of new purchases etc.). In this logic the customer will pay to the supplier an initial fee plus a recurrent regular amount based on some metrics (E.g. Software as a service SaaS). In this logic the VAs is programmed to be somehow specialist in the customer's sector or discipline. You cannot ask a VA deployed for commercial bank information and/or services about other companies or industries.

Business-to-Consumers: In this logic a private company designs a VA that can be integrated into another product (E.g. Siri in the Iphone4S) as an additional functionality. In the case of Siri, Apple included this virtual assistant free in their smartphones three years ago, and there are plans to develop a Siri-controlled Apple TV or to include Siri in the iWatch in the near future. Another possibility is the approach by Sherpa which offered a VA as an App (to be downloaded free in android) and with a business model based on different monetization techniques, including innovative systems for advertising, affiliate programs, payment transactions, premium services, licensing, among others. In this B2C logic the argument that supports the value proposal is somehow built around the idea that this system might be your universal interface not only to your specific device (I.e. smartphone) but to your digital world.

Despite the attractive possibilities VAs offer compared to TBSS systems, these intelligent systems open important 
doubts and questions including: what are the pros and cons of the proactivity potential of these systems?, What happens with issues related to privacy and confidentiality?, What psychological and sociological impacts can these systems have on people and society?. To illustrate these points let's consider the following example that was discussed with the experts:

- Suppose that you are walking along the street wearing the Google Glasses and suddenly your VA (in this case a free App that you have downloaded in your device) appears in your glasses and your VA advices that you are near a shop with your preferred brands at sale price. Here the logic is commercial proactivity. You continue walking and your VA warns you that you are in danger because a bus might hit you because you are crossing with the traffic lights changing from green to yellow. The system is able to do this because it is connected to sensors in the smart city and the device knows your position via geolocation. Here the logic is a personal security proactivity. This is very good for you because you avoid an accident but is also very good for the city's health system because they will not have to take care of you in the hospital saving money and resources for the community.

In this case the experts considered that this could open possibilities to build an innovative business model connecting the private and public sector. Experts believe that it is important to differentiate between commercial proactive services and human/social proactive services but as one expert said "thanks to these technologies we will see more and more win-win business models connecting the private and public sector". The key issue is how to do this in practice.

\section{Conclusions}

In this paper several types of service delivery have been explored. This has been done by interviewing expert informants. The paper's qualitative approach provides in depth insights about the use of state of art technologies such as VAs for service delivery. The analysis of the literature and the interviews with the experts show that:

1. There will be room for the three types of service deliveries identified, (1) services delivered by humans, (2) services delivered by TBSS systems, (3) services delivered by intelligent machines such as Virtual Assistants $5^{\circ}$ generation.

2. In the future customers will continue performing the service or parts of the service by themselves with the use of TBSS systems. In other words intelligent machines will not kill self-service technologies because the business model and value proposition of each type of service is interesting for a type of customer segment.

3. Users will not be able to absorb all the technological developments at the same speed as the innovations are coming out into the marketplace. Experts don't see dramatic changes of uses and habits with new intelligent technologies. They believe that customers will use intelligent machines only if they see clear added value.

Base on this study this author believes that there might be a mixture of different types of service delivery alternatives including humans, TBSS and intelligent systems. This investigation opens areas for further research including:

- Technology adoption: There are many empirical studies investigating the adoption of TBSS systems. One problem to the knowledge of this author is that there are very few studies investigating the adoption of intelligent services such as VAs, therefore further investigation in this area will be needed. Several disciplines could investigate these systems: marketing, consumer behaviour, psychology, sociology, innovation etc. For instance, if people adopt the technology, could they get addicted to these systems?

- Monofunctional vs multifunctional and reactive vs proactive: Some specific questions arise in relation to the convenience of developing monofunctional and/or multifunctional and reactive and/or proactive intelligent services.

- Privacy and confidentiality: These issues are attracting a lot of interest in digital social networks such as Facebook or Twitter and this author believes this will be an area that deserves attention.

- Business Models and value propositions: Some practical questions arise for the service provider in relation to finding the way to offer on a continuous basis the right mixture of different types of service delivery alternatives.

- Collaboration between firms and other stakeholders: Collaboration between firms and other key stakeholders is becoming more important (Lowitt [45]). Value is no longer created by firms acting alone; instead firms are acting together with external parties through informal arrangements or formal alliances (Beattie and Smith [31], Bocken, et al. [46]). The case of Virtual Assistants shows how value might benefit not only the customer and the final user but society in general. A question arises in relation to the need of investigating the different types of service delivery alternatives not only from the perspective of the service provider and the customer but from a holistic point of view.

\section{REFERENCES}

[1] Lovelock, C.H. and Wright, L. (1998), Principles of Service Marketing and Management. Upper Saddle River, NJ, Prentice Hall. 
[2] Zeithaml, V.A. and Bitner, M.J. (2003), Services Marketing: Integrating Customer Focus across the Firm, $3^{\text {rd }}$ Edition, New York, NY: McGraw-Hill.

[3] Vargo, S.L. and Lusch, R.F. (2004), "Evolving to a New Dominant Logic for Marketing", Journal of Marketing, Vol. 68 , No. January, pp 1-17.

[4] Kelley, S.W., Donnelly, J.H.J., et al. (1990), "Customer Participation in Service Production and Delivery", Journal of Retailing, Vol. 66, No. 3, pp 315-335.

[5] Gummesson, E. (2002), "Relationship Marketing and a New Economy: it's Time for de-Programming", The Journal of Services Marketing, Vol. 16, No. 7, pp 585-589.

[6] Meuter, M.L., Bitner, M.J., Ostrom, A.L., and Brown, S.W. (2005), "Choosing Among Alternative Service Delivery Modes: An Investigation of Consumer Trial of SSTs, Journal of Marketing, Vol. 69, No. April, pp 61-83.

[7] Czepiel, J. A. (1990), "Service Encounters and Service Relationships: Implications for Research", Journal of Business Research, Vol. 20, pp 13-21.

[8] Sheth, J.N., Sisodia, R.S., et al. (2000), "The Antecedents and Consequences of Customer-Centric Marketing", Journal of the Academy of Marketing Science, Vol. 28, No. 1, pp 55-66.

[9] Day, G. and Montgomery, D. (1999), "Charting New Directions for Marketing", Journal of Marketing, Vol. 63, No. Special Issue, pp 3-13.

[10] Michel, S., Brown, S. W. and Gallan, A. S. (2008), “An Expanded and Strategic View of Discontinuous Innovation: Deploying a Service-Dominant Logic", Journal of the Academy of Marketing Science, Vol. 36, pp 54-66.

[11] Bitner, M.J., Brown, S.W. and Meuter, M.L. (2000), "Technology Infusion in Service Encounters", Journal of the Academy of Marketing Science, Vol. 28, No. 1, pp 138-149.

[12] Froehle, C. M. (2006), "Service Personnel Technology, and Their Interaction in Influencing Customer Satisfaction" Decision Sciences, Vol. 37, No. 1, pp 5-38.

[13] Regan, W.J. (1963), "The Service Revolution", Journal of Marketing, Vol. 27, No. July, pp 57-62.

[14] Anselmsson, J. (2001), "Customer-Perceived Service Quality and Technology-Based Self-Service”, Doctoral Dissertation, Lund University, Lund, Sweden: Lund Business Press.

[15] Dabholkar, P.A. (1994a), “Technology-Based Service Delivery: a Classification Scheme for Developing Marketing Strategies", In Swartz, TA. Bowen, D.E. and Brown, S.W. (Ed.), Advances In Services Marketing and Management, JAI Press Inc., Greenwich, CT, Vol. 3, pp 241-271.

[16] Dabholkar, P.A. (1994b), "Incorporating Choice into an Attitudinal Framework: Analyzing Models of Mental Comparison Processes", Journal of Consumer Research, Vol. 21, pp 100-118.

[17] Meuter, M.L., Bitner, M.J. (1998), "Self-Service Technologies: Extending Service Frameworks and Identifying Issues for Research", In AMA Winter Educators' Conference Proceedings: in Marketing Theory and Applications, Dhruv Grewal and Connie Pechmann, (Eds), Chicago. American Marketing Association, Vol. 9, pp 12-19.

[18] Dabholkar, P.A. (1996), "Consumer Evaluations of New
Technology-Based Self-Service Options: an Investigation of Alternative Models of Service Quality", International Journal of Research in Marketing, Vol. 13, pp 29-51.

[19] Newholm, T., Laing, A., et al. (2006), "Assumed Empowerment: Consuming Professional Services in the Knowledge Economy", European Journal of Marketing, Vol. 40, No. 9-10, pp 994-1012.

[20] Alba, J., Lynch, J., et al. (1997), "Interactive Home Shopping: Consumer, Retailer, and Manufacturer Incentives to Participate in Electronic Marketplaces", Journal of Marketing, Vol. 61, No. July, pp 38-53.

[21] Dabholkar, P.A. and Bagozzi, R.P. (2002), “An Attitudinal Model of Technology-Based Self-Service: Moderating Effects and Situational factors", Journal of the Academy of Marketing Science, Vol. 30, No.3, pp 184-201.

[22] Schultze, U. (2004), "Complementing Self-Service Technology with Service Relationships - The Customer Perspective", e-Service Journal, Vol. 3, No. 1, pp 7-31.

[23] Sousa, R. and Voss, C. (2006), "Service Quality in Multi-channel Services Employing Virtual Channels", Journal of Service Research, Vol. 8, No. 4, pp 356-371.

[24] Cunningham, L., Young, C. and Gerlach, J.(2008), "Consumer Views of Self-Service Technologies, The Service Industries Journal, Vol. 28, No. 6, pp 719-32.

[25] Osterwalder, A., Pigneur, Y., (2005), "Clarifying Business Models: origins, Present, and Future of the Concept). Commun. AIS 15 (May).

[26] Rasmussen, B., (2007), "Business Models and the Theory of the Firm", Working Paper. Victoria University of Technology, Melbourne, Australia.

[27] Chesbrough, H., (2010), "Business Model Innovation: Opportunities and Barriers", Long Range Plann. Vol. 43, No. 2-3, pp 354-363.

[28] Zott, C., Amit, R., Massa, L., (2011), “The Business Model: Recent Developments and Future Research", J. Manag. Vol. 37, No. 4, pp. 1019-1042.

[29] Magretta, J., (2002), “Why Business Models Matter”, Harvard Bus. Vol. 80, No. 5, pp. 86-92.

[30] Zott, C., Amit, R., (2010), "Business Model Design: an Activity System Perspective", Long Range Plan, Vol. 43, No. 2/3, pp. 216-226.

[31] Beattie, V., Smith, S., (2013), "Value Creation and Business Models: Refocusing the Intelectual Capital Debate". Br. Acc. Rev.. http://dx.doi.org/10.1016/j.bar.2013.06.001.

[32] Teece, D., (2010), "Business Models, Business Strategy and Innovation", Long Range Planning, Vol. 43, No. 2-3, pp. 172-194.

[33] Dalebout, A. and Wierenga, B. (1997), "Qualitative modelling of sales promotion decision making based on verbal data", 26th EMAC Conference Proceedings, 20-23 May, Warwick Business School, Warwick.

[34] Winkler, R.L. (1981), "Combining Probability Distributions from Dependent Information Sources”, Management Science, Vol. 27, No. 4, pp. 479-488.

[35] Kent, R. (2007), Marketing Research: Approaches, Methods 
and Applications, London: Thomson Learning.

[36] Curran, J.M. and Meuter, M.L. (2005), "Self-Service Technology Adoption: Comparing Three Technologies", Journal of Services Marketing, Vol. 19, No. 2, pp 103-113.

[37] Svensson, G. (2006), "New Aspects of Research into Service Encounters and Service Quality", International Journal of Service Industry Management, Vol. 17, No. 3, pp 245-257.

[38] Harris, L.C. and Ogbonna, E. (2006), "Service Sabotage: A Study of Antecedents and Consequences", Journal of the Academy of Marketing Science, Vol. 34, No. 4, pp 543-558.

[39] Bitner, M. J., Booms, B., et al. (1994), "Critical Service Encounter: The Employee's Viewpoint", Journal of Marketing, Vol. 58, No. October, pp 95-106.

[40] Yen, H.J., Gwinner, K.P., et al. (2004), "The Impact of Customer Participation and Service Expectation on Locus Attributions Following Service Failure", International Journal of Service Industry Management, Vol. 15, No. 1, pp 7-26.

[41] Swanson, S.R. and Kelley, S.W. (2001), "Attributions and Outcomes of the Service Recovery Process", Journal of
Marketing Theory and Practice, Vol. Fall, pp 50-65.

[42] Bitner, M.J., Booms, B. and Tetreault, M.S. (1990), “The Service Encounter Diagnosing Favourable and Unfavourable Incidents", Journal of Marketing, Vol. 54, No. January, pp 71-84.

[43] Dabholkar, P.A., Bobbitt, L.M. and Lee, E.J. (2003), "Understanding Consumer Motivation and Behaviour related to Self-scanning in Retailing: Implications for Strategy and Research on Technology-Based Self-service", International Journal of Service Industry Management, Vol. 14, No. 1, pp 59-95.

[44] Lin, M. and Salomonson, N., (2006), "The Role of Virtual Servants in e-Interaction", First International Pragmatic Web Conference, September 21-23, Stuttgart, Germany.

[45] Lowitt, E., 2013. The Collaborative Economy. Jossey-Bass (Wiley), San Francisco, USA.

[46] Bocken, N.M.P. Short, S.W., et al. (2014), "A Literature and Practice Review to Develop Sustainable Business Model Archetypes", Journal of Clearer Production, Vol. 65, pp. 42-56. 